\title{
IMPLEMENTATION OF RISK ASSESSMENT FOR CRITICAL INFRASTRUCTURE PROTECTION WITH THE USE OF RISK MATRIX
}

\author{
Olena Ivanenko ${ }^{1}$ \\ ${ }^{1}$ Department of Ecology and Technology of Plant Polymers, National Technical University of Ukraine «Igor Sikorsky Kyiv Polytechnic \\ Institute», Kyiv, Ukraine \\ olenka.vasaynovich@gmail.com
}

ARTICLE INFO

Article history:

Received date 18.03 .2020

Accepted date 09.04.2020

Published date 30.04.2020

Section:

Safety, Risk, Reliability and Quality

D O I

$10.21303 / 2313-8416.2020 .001340$

KEYW ORDS

risk

economic losses

emergency situations

critical infrastructure

consequences

threats

priorities

\section{ABSTRACT}

The object of research: risk assessment for critical infrastructure protection in Ukraine. Investigated problem: adaptation and implementation of European Union's approach to the risk assessment for critical infrastructure for the conditions of Ukraine.

The main scientific results: The most relevant types of threats of natural and man-made origin for the security of critical infrastructure in Ukraine are investigated. The adaptation and implementation of European Union's approach to the risk assessment for critical infrastructure for the conditions of Ukraine is realized. For this the character of changes of natural and man-made emergencies in Ukraine in the context of impact on critical infrastructure is investigated. The risk of economic losses due to emergencies in Ukraine has been evaluated with the use of risk matrix, taking into account the adapted approach applied in the European Union.

Field of practical use of research results: Critical infrastructure facility including systems and physical or virtual resources that provide functions and services, failure of which can lead to significant negative consequences for society, social and economic development of the country and ensuring national security. Among them the most important are objects of electric-power industry, especially important objects of the oil and gas industry; units of the state government and local administration; objects of possible terrorist attacks; facilities subject to protection and defense in emergencies and during special periods; facilities subject to mandatory protection by the State Protection Service under contracts.

Innovative technology product: methodology for assessing threats and risks to critical infrastructure, which can greatly contribute to the development of measures to prevent and minimize the negative consequences of emergencies possible in Ukraine at critical infrastructure objects.

Scope of the innovative technology product: state system for critical infrastructure protection in Ukraine.

(C) The Author(s) 2020. This is an open access article under the CC BY license http://creativecommons.org/licenses/by/4.0).

\section{Introduction}

In many countries around the world, especially EU and NATO member states critical infrastructure protection is recognized as a priority in national security policy. As a result, these countries are actively developing national systems for protection (security) and resilience of critical infrastructure, adopting legislative documents to regulate the risk assessment, training relevant staff, establishing partnerships with the private sector, educational activities. In the US the Department of Homeland Security primarily conducts assessments for each of the three elements of risk - threat, vulnerability, and consequence for critical infrastructures from the three sectors Critical Manufacturing; Nuclear Reactors, Materials, and Waste; and Transportation Systems.

\section{1. The object of research}

Risk assessment for critical infrastructure protection in Ukraine.

\section{2. Problem description}

The operation of numerous mining, chemical, energy companies, the large number of industrial-urban agglomerations, and the high population density in them cause the increase of the risk 
of emergencies with large-scale negative consequences due to the threat of damage and destruction of critical infrastructure (CI) facilities. Among such objects, spatially distributed railway tracks, oil and gas pipelines, bridges, potentially dangerous production facilities, truck power grids, whose safe operation is supremely important for the socio-economic development of Ukraine, are particularly concerned.

Critical infrastructure of Ukraine is systems and physical or virtual resources that provide functions and services, failure of which can lead to significant negative consequences for society, social and economic development of the country and ensuring national security [1]. The national legislation defines the following categories of objects with special conditions for their protection and functioning, which may belong to critical infrastructure according to world practice [1]:

- companies of strategic importance for the economics and security of the state;

- particularly important objects of electric-power industry;

- especially important objects of the oil and gas industry;

- important state-owned objects, in particular the units of the state government and local administration;

- objects of possible terrorist attacks;

- facilities subject to protection and defense in emergencies and during special periods;

- facilities subject to mandatory protection by the State Protection Service under contracts;

- public authorities subject to free protection by the National Guard of Ukraine;

- high risk objects;

- objects included in the State Register of Potentially Dangerous Objects;

- radiation hazardous objects for which a project threat is being developed;

- objects classified as civil protection;

- objects belonging to business entities, the design of which is carried out in accordance with the requirements of engineering and technical measures of civil protection;

- dispatch system for emergency assistance to the population via a single toll-free emergency number 112;

- emergency rescue services;

- National confidential communication system;

- State system of government communication of Ukraine;

- payment systems;

- immovable cultural heritage sites.

In accordance with the Civil Protection Code of Ukraine, an emergency situation is the situation in a certain territory or business entity on it or on a water body, characterized by a violation of normal living conditions of the population, caused by a catastrophe, accident, fire, natural disaster, epidemic, epizootic, epiphytoxics, the use of means of destruction or by another dangerous incident that led (may lead) to a threat to the life or health of the population, to a large number of dead and injured, causing significant material losses, as well as the impossibility for the population to live in such a territory or facility, to carry out economic activity on it [2].

A threat is considered as a dangerous phenomenon, substance, human activity or condition that can lead to social and economic losses, loss of life, injury or other consequences for public health, loss of property, livelihoods and services, environmental damage [3].

In this paper, risk is considered as a combination of the negative consequences of an incident or a threat and associated probability of its occurrence [4].

\section{3. Suggested solution to the problem}

The investigation of the basic tendencies and nature of changes of emergencies of natural and man-made origin in the world convinces that there is an increasing risk of their occurrence [5]. Current programs and reports of the UN and the World Bank on the consequences of natural disasters and man-made disasters in recent years show a significant increase in economic losses because of them $[5,6]$. The main approaches to assessing the risk of emergencies of different origin, used in Ukraine $[7,8]$ and the world $[9,10]$, are analyzed.

In [11], an assessment of the risk of death due to emergencies has already been carried out in the context of critical infrastructure protection. However, an important aspect regarding the risk of economic loss was not taken into account in the publication. In today's context, this is fundamen- 
tally important, given the limited resources for protecting critical infrastructure and the growing threats of natural origin caused by climate change

The analysis shows the growing threat of a decrease in the security level of numerous critical infrastructure facilities in Ukraine due to the over-exploitation of structures, constructions, equipment and engineering networks that operate on the brink of exhaustion of their resources and pose serious risks of natural and man-made emergencies for the safe operation of critical infrastructure objects $[12,13]$.

In addition, in the context of the military conflict in the Donbass (Ukraine) due to the destruction of many industrial and residential buildings as a result of military operations, there is an increased risk of emergencies of anthropogenic origin. The destruction and damage of many critical infrastructure facilities, including water treatment plants, chemical plants and agricultural enterprises caused by military actions, pose a serious threat to the population and the environment.

Studies in the field of prevention and counteraction to threats of different origin indicate that the state system of protection of the population from natural and man-made emergencies requires the introduction of a risk-oriented approach to effectively prevent and reduce the risk of catastrophes of different origin for critical infrastructure objects [14, 15].

It should also be taken into account that the negative nature of changes in environmental and man-made threats that occurs due to pollution of atmospheric air, river basins and groundwater, the destruction of landscapes and objects of the nature reserve, significantly reduces the level of safety of life of the population in the area of military conflict in eastern Ukraine, as well as in other environmentally related territories of Donetsk and Luhansk regions.

The presence of a large number of flooded and semi-flooded mines, which have permanent hydraulic connection with operating mines in the territory of Lugansk and Donetsk regions, is the great threat of emergencies of natural and man-made origin. The poor environmental status of the coal-mining areas, especially in the Donbas region, is also complicated by the high concentration of metallurgical and chemical companies, which increases the anthropogenic burden on the environment and poses real threats to public health.

In addition to the Donetsk and Luhansk regions, Zaporizhzhia and Dnipro regions belong to the industrialized areas of Ukraine with the predominance of heavy industry with the highest concentration of mining and processing companies. In particular, it can be noted that the Zaporizhzhia region, especially the city of Zaporizhzhia (Ukraine), belong to the territories of significant manmade impact. Increased anthropogenic load on the air, soil and water bodies is formed not only by a large number of industrial companies, but also due to the inefficient operation of gas treatment facilities, domestic and industrial waste water treatment facilities. One of the most significant and toxic pollutants of the city's atmospheric air is carbon monoxide, which concedes only to alcohol and poisoning at work and at home [16].

The list of environmentally hazardous objects of Zaporizhzhia (Ukraine) includes PJSC "Ukrainian Graphite" - a well-known manufacturer of graphite electrodes for electric smelters and other types of electric furnaces, commercial carbon masses for electrodes [17-19]. This company together with other industrial companies-polluters of Zaporizhzhia, whose emissions make up 60$70 \%$ of the total gross amount of pollutant emissions, makes a major contribution to the air pollution of the city. Along with the emissions of solids particles, nitrogen and sulfur oxides, the share of toxic carbon monoxide emissions is $42 \%$ of the total emissions of the facility [20]. Given the importance and scale of production, an object such as PJSC "Ukrainian Graphite" can be attributed to critical infrastructure.

\subsection{Suggested solution to the problem}

The aim of research is the analysis of the nature of changes in natural and man-made emergencies in Ukraine, the adaptation of international experience in national risk assessment for critical infrastructure, possibility of its implementation and practical application in Ukraine, the risk assessment of economic losses due to emergencies of different origin in Ukraine, emphasizing attention to the Zaporizhzhia region.

During 2000-2010 there were 4459 emergencies of different origin in Ukraine, among them 1939 had natural character, 2299 were of man-made and 221 of social origin (Table 1). The economic losses because of these emergencies amounted to 11689089 thousand UAH. 
Table 1

Characteristics of emergencies in Ukraine during 2000-2010

\begin{tabular}{|c|c|c|}
\hline Type of emergency & $\begin{array}{c}\text { Number of } \\
\text { emergencies }\end{array}$ & $\begin{array}{l}\text { Economic losses, } \\
\text { thousand UAH }\end{array}$ \\
\hline \multicolumn{3}{|l|}{ Emergencies of anthropogenic nature } \\
\hline $\begin{array}{l}\text { Emergencies due to accidents or disasters at transportation } \\
\text { (except fires and explosions) }\end{array}$ & 541 & 62703 \\
\hline Emergencies due to fires, explosions & 928 & 1015453 \\
\hline $\begin{array}{l}\text { Emergencies as a result of accidents involving the emissions (threat of emissions) of } \\
\text { hazardous chemicals, minerals at other sites (except traffic accidents) }\end{array}$ & 26 & 85 \\
\hline $\begin{array}{l}\text { Emergencies due to the presence of harmful (polluting) and radioactive substances } \\
\text { above MPC in the environment }\end{array}$ & 124 & 76038 \\
\hline $\begin{array}{l}\text { Emergencies due to accidents involving emissions (threat of emissions) of } \\
\text { radioactive substances (except traffic accidents) }\end{array}$ & 3 & 0 \\
\hline Emergencies as a result of sudden destruction of buildings and structures & 120 & 101764 \\
\hline Emergencies due to accidents in electric power systems & 277 & 41714 \\
\hline Emergencies due to accidents in life support systems & 249 & 216210 \\
\hline Emergencies due to crash of telecommunication systems & 21 & 2474 \\
\hline Emergencies caused by accidents at treatment plants & 8 & 20477 \\
\hline Emergencies due to accidents in the systems of oil and gas industrial complex & 2 & 125 \\
\hline \multicolumn{3}{|l|}{ Emergencies of natural character } \\
\hline Geophysical emergencies & 2 & 1028 \\
\hline Geological emergencies & 117 & 467714 \\
\hline Meteorological emergencies & 780 & 4681500 \\
\hline Hydrological marine emergencies & 8 & 14478 \\
\hline Hydrological emergencies of surface waters & 60 & 4845643 \\
\hline Emergencies related to fires in natural ecological systems & 157 & 106454 \\
\hline Medical and biological emergencies & 815 & 34366 \\
\hline \multicolumn{3}{|l|}{ Emergencies of social character } \\
\hline $\begin{array}{l}\text { Armed attacks, seizing or retention of objects of the state importance (the most } \\
\text { important and important state objects) or the real threat of such actions }\end{array}$ & 1 & 0 \\
\hline Infringement on life of a statesman or a public figure & 4 & 25 \\
\hline $\begin{array}{l}\text { Installation of an explosive device in a crowded place, institution (organization, } \\
\text { company), residential area, transportation }\end{array}$ & 42 & 36 \\
\hline $\begin{array}{l}\text { Emergencies related to the disappearance or theft of weapons and dangerous } \\
\text { substances from objects of their storage, use, processing or during transportation }\end{array}$ & 18 & 0 \\
\hline Emergencies related to accidents with people & 156 & 802 \\
\hline Total & 4459 & 11689089 \\
\hline
\end{tabular}

Source: [21]

As for 2017, in the first quarter of this year, 48 emergencies were registered in Ukraine, including 14 of man-made, 33 of natural and 1 of social character [22]. During these emergencies, 47 people were killed and 261 were injured. Compared to the same period of 2016, the total number of emergencies in 2017 increased by $71.4 \%$, while the number of emergencies of anthropogenic nature did not change, and the number of natural emergencies more than doubled, which is explained by the increase in the share of biomedical emergencies. As for the characteristics of the emergencies during the years 2018-2019, the use of such information is not for general access.

It should be particularly emphasized the cases of increased risk of emergencies of anthropogenic origin in the Antiterrorist operation (ATO) zone due to the destruction of many industrial and residential buildings as a result of military operations. The damage of critical infrastructure, including water treatment plants, chemical plants and agricultural companies, caused by the military conflict in eastern Ukraine, poses a serious threat to the population and the environment, not 
only in Donetsk and Luhansk regions, but also in the whole Ukraine. Therefore, the protection of infrastructure in a military conflict is extremely important. The OSCE has repeatedly called on the conflicting parties in the Donbass to make every effort to protect the vital civilian infrastructure of the region, as damage to any of them can lead to an environmental disaster that would significantly worsen the condition of the population on both sides of the warfare line [23].

Given the transboundary scale of the impact of emergencies of various origins, international cooperation in the area of disaster risk reduction is of extremely important for Ukraine. The importance and the need to coordinate efforts to reduce the risk of emergencies at the international, regional and local levels has been emphasized in recent years in a number of multilateral framework programs and declarations. Among them, the «Yokohama Strategy and Plan of Action for a Safer World. Guidelines for Natural Disaster Prevention, Preparedness and Mitigation», which was adopted in 1994, is important and at present it is the UN basic document in the field of disaster risk reduction and mitigation of their negative consequences [24].

The Third UN World Conference on Disaster Risk Reduction, held on March 14-18, 2015 in Sendai (Miyagi Prefecture, Japan), adopted the Sendai Framework for Disaster Risk Reduction 2015-2030 [25].

Disaster risk reduction is a globally recognized integrated approach that involves the working out of targeted political, technical, social and economic measures. Such activities can take many forms, such as strategic guidelines, legislation, preparedness plans, agricultural projects, insurance programs etc. This approach takes into account the needs of the entire society in a safe living environment by making sound management decisions in the area of disaster risk reduction and minimizing their negative effects on the population, critical infrastructure and the environment.

In general, this approach involves the fulfillment of relevant tasks at the state level, the most important of which is the inclusion of disaster risk reduction measures in socio-economic development plans and programs [25]. The ultimate goal is to prevent the emergence of new and reduce known risks of catastrophes by undertaking integrated and inclusive economic, structural, legal, social, health, cultural, educational, environmental, technological, political and institutional measures that prevent and reduce exposure to hazardous factors and vulnerability to disasters, increase readiness for response and recovery, and thereby strengthen the capacity of the state to counteract.

Disaster risk reduction should be undertaken at local, regional and national levels, taking into account the following priorities [25]: understanding of disaster risk; improvement of the organizational and legal framework for disaster risk management; investment in disaster risk reduction measures to enhance counteraction potential; increasing disaster preparedness to ensure effective response and the implementation of the «Do better than it was» principle in recovery, rehabilitation and reconstruction activities.

An important task here is to implement disaster risk reduction activities as an integral part of civil protection strategies and programs and to increase the resilience of the state to the impact of defeating factors. Particular attention should be paid to ensuring the stability of health facilities and water supply infrastructure to provide access to rescue emergency services and water supply in emergency situations.

The positive experience of many countries indicates that the creation of an effective disaster risk reduction mechanism in Ukraine will have several benefits, including: improved coordination with neighboring countries, attraction of resources from private companies and international organizations, sharing experience with disaster risk reduction specialists in different countries, as well as enhancing the positive image of our country through the introduction of globally recognized risk-oriented approaches to increase the resilience of the state to the impact of emergency situations of different origin.

\section{Materials and methods}

This paper performs a risk assessment, which generally involves several steps:

- identification of risks as a process of their identification and description;

- risk analysis, which involves understanding the nature of the risk and determination of its level;

- risk assessment, which involves comparison of the results of a risk analysis with the criteria for determination whether the risk is acceptable or tolerable. 
If the problem of prevention and preparedness for a particular type of threat is addressed, the risk can be quantified as a function of the probability of threat, exposure (total cost of all elements exposed to risk) and vulnerability (specific impact on exposure) [26].

In the EU countries, in order to conduct a National Risk Assessment for critical infrastructure, it is recommended to use a risk matrix of $5 \times 5$ as a means to visualize the results of the assessment (Fig. 1).

Risk assessment should be based on three different categories of impact and take into account the negative consequences for humans (population), the economy (and the environment), as well as the political and social consequences. At the same time, for the first two categories of impact, the negative consequences are defined in quantitative terms as the number of dead (injured) persons or economic losses in UAH (EUR). The consequences for the third category of influence, given the social and political linkages, are determined by qualitative indicators.

In the European Union, each country must carry out a risk assessment for each impact category and build three different risk matrices correspondingly when conducting a risk assessment for critical infrastructure. Among all threats of various origins to security of critical infrastructure (CI), the following are identified as the most important [26]:

- natural: floods, extreme weather events, forest fires, earthquakes, epidemics and pandemics, epizootics;

- man-made:

a) unintentional: industrial accidents, nuclear/radiological accidents, traffic accidents, loss of critical infrastructure;

b) malicious: cyber attacks, terrorist attacks.

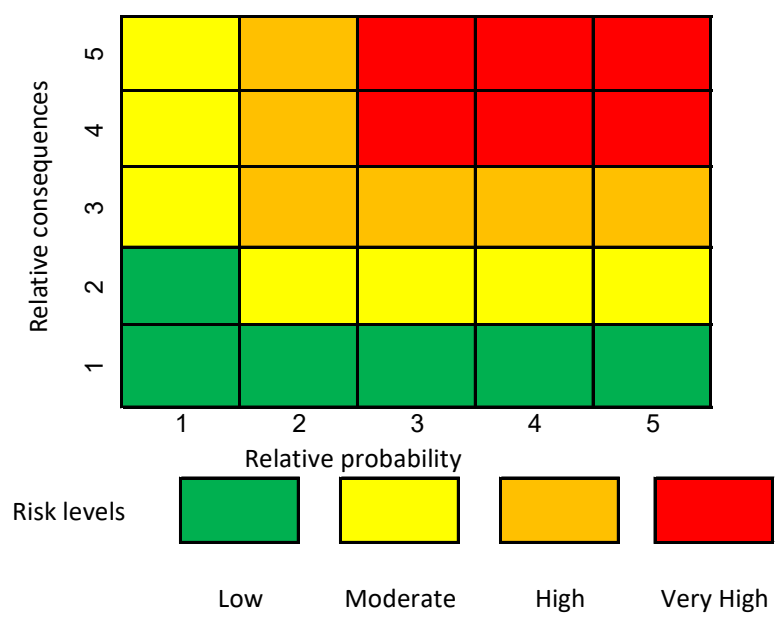

Fig. 1. Sample of risk matrix Source: [26]

Particular attention needs to be paid to the interrelationships and interdependencies between threats of natural origin, when the emergence of some dangerous phenomena leads to the formation of new ones through the mechanism of cascading effects (Table 2).

Realization of the cascading effects of modern threats is quite difficult due to the relationship between infrastructure objects and their environment. The failure of stakeholders and political leaders to agree on forecasting and mitigating the negative effects of new threats, especially those of natural origin, could lead to serious disruptions to critical infrastructure in the nearest future.

In this paper, the risk assessment of the economic losses from emergencies of natural and man-made origin is carried out according to the available data of the State Emergency Service of Ukraine on emergency situations of various origins, therefore, a risk matrix is built. Using statistical data, the probability of occurrence of dangerous situations and the probability of economic losses because of them are calculated and, on this basis, the corresponding dependence is formed, which was done to reach the aim of this publication (Fig. 2). The probability of an emergency was defined as the ratio of the number of emergencies of the certain type to the total number of emergencies that occurred during 2000-2010. 
Table 2

Relationships and interdependencies between threats

\begin{tabular}{cc}
\hline Threat & Related threats \\
\hline Dangerous weather phenomena & $\begin{array}{c}\text { Floods, landslides, forest fires, pollution, } \\
\text { loss of critical infrastructure, traffic accidents }\end{array}$ \\
Landslides, tsunami \\
Landslides, earthquakes, volcanoes \\
$\begin{array}{c}\text { Nuclear, chemical and traffic accidents, } \\
\text { loss of critical infrastructure } \\
\text { Loss of critical infrastructure } \\
\text { Pollution }\end{array}$
\end{tabular}

Source: [26]

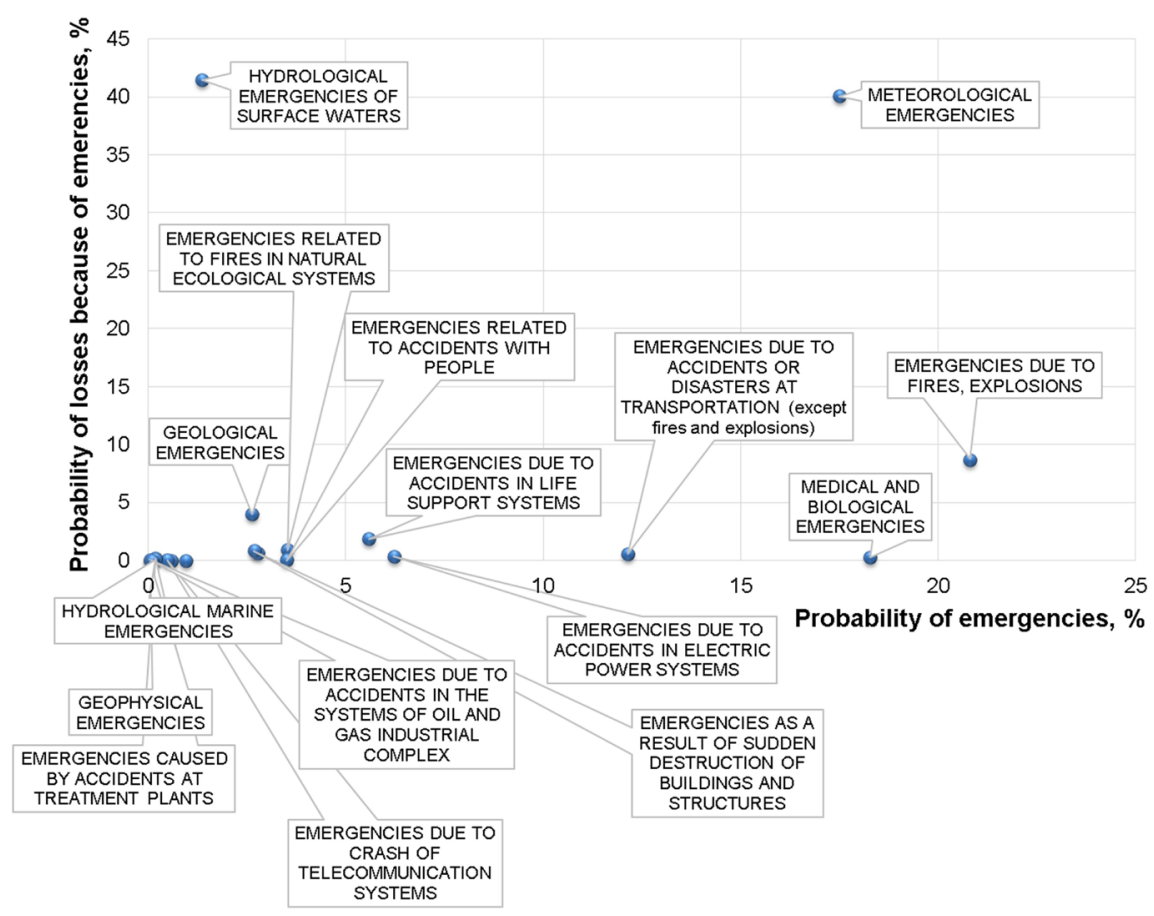

Fig. 2. The relationship between the probabilities of emergencies and economic losses due to emergencies during 2000-2010

Source: calculation of the authors

On this basis, the distribution of the probability values of the occurrence of threats and economic losses is determined, and the importance categories are estimated depending on the probability values of emergencies. Further, taking into account the results of likelihood assessment of emergencies and the economic losses because of them, a risk matrix is built in accordance with the model used in the EU.

\section{1. Experimental procedures}

Obviously the obtained probability values do not fully reflect the overall picture, because they are not comparable in this case. There is a need for further generalization in order to bring the obtained values to the type used in the EU. To do this, the probability values of threats and economic losses due to them were divided into five categories, of which 5 reflects the most likely event (Table 3).

The probability value for emergencies due to accidents or traffic disasters means that 541 emergencies of this type with a probability of $12.13 \%$ may happen within 11 years. Given the high probability value, it can be referred to the 4th category of importance on the corresponding scale (Table 4). 
Table 3

Distribution of probability values of occurrence of threats and economic losses

\begin{tabular}{|c|c|c|c|c|c|}
\hline Type of emergency & Code & $\begin{array}{l}\text { Amount of } \\
\text { losses, } \\
\text { thousand UAH }\end{array}$ & $\begin{array}{l}\text { Probability of } \\
\text { occurrence of } \\
\text { emergency, \% }\end{array}$ & $\begin{array}{c}\text { Category of } \\
\text { probability of } \\
\text { economic losses }\end{array}$ & $\begin{array}{l}\text { Category of } \\
\text { probability of occur- } \\
\text { rence of emergency }\end{array}$ \\
\hline $\begin{array}{l}\text { Emergencies due to accidents or } \\
\text { disasters on transportation }\end{array}$ & 1 & 62703 & 12.13277 & 2 & 4 \\
\hline $\begin{array}{l}\text { Emergencies due to fires, } \\
\text { explosions }\end{array}$ & 2 & 1015453 & 20.81184 & 4 & 5 \\
\hline $\begin{array}{l}\text { Emergencies as a result of } \\
\text { accidents involving the emissions } \\
\text { (threat of emissions) of hazardous } \\
\text { chemicals, minerals at other sites } \\
\text { (except traffic accidents) }\end{array}$ & 3 & 85 & 0.58309 & 1 & 1 \\
\hline $\begin{array}{l}\text { Emergencies due to the presence } \\
\text { of harmful (polluting) and } \\
\text { radioactive substances above MPC } \\
\text { in the environment }\end{array}$ & 4 & 76038 & 2.780893 & 2 & 2 \\
\hline $\begin{array}{c}\text { Emergencies as a result of sudden } \\
\text { destruction of buildings and } \\
\text { structures }\end{array}$ & 5 & 101764 & 2.691186 & 3 & 2 \\
\hline $\begin{array}{l}\text { Emergencies due to accidents in } \\
\text { electric power systems }\end{array}$ & 6 & 41714 & 6.212155 & 2 & 3 \\
\hline $\begin{array}{l}\text { Emergencies due to accidents in } \\
\text { life support systems }\end{array}$ & 7 & 216210 & 5.584212 & 3 & 3 \\
\hline $\begin{array}{l}\text { Emergencies due to crash of } \\
\text { telecommunication systems }\end{array}$ & 8 & 2474 & 0.470958 & 1 & 1 \\
\hline $\begin{array}{l}\text { Emergencies caused by accidents } \\
\text { at treatment plants }\end{array}$ & 9 & 20477 & 0.179412 & 2 & 1 \\
\hline $\begin{array}{l}\text { Emergencies due to accidents in } \\
\text { the systems of oil and } \\
\text { gas industrial complex }\end{array}$ & 10 & 125 & 0.044853 & 1 & 1 \\
\hline Geophysical emergencies & 11 & 1028 & 0.044853 & 1 & 1 \\
\hline Geological emergencies & 12 & 467714 & 2.623907 & 4 & 3 \\
\hline Meteorological emergencies & 13 & 4681500 & 17.49271 & 5 & 5 \\
\hline Hydrological marine emergencies & 14 & 14478 & 0.179412 & 2 & 1 \\
\hline $\begin{array}{l}\text { Hydrological emergencies of } \\
\text { surface waters }\end{array}$ & 15 & 4845643 & 1.345593 & 5 & 2 \\
\hline $\begin{array}{l}\text { Emergencies related to fires in } \\
\text { natural ecological systems }\end{array}$ & 16 & 106454 & 3.520969 & 3 & 2 \\
\hline $\begin{array}{l}\text { Medical and biological } \\
\text { emergencies }\end{array}$ & 17 & 34366 & 18.27764 & 2 & 5 \\
\hline $\begin{array}{c}\text { Infringement on life of a statesman } \\
\text { or a public figure }\end{array}$ & 18 & 25 & 0.089706 & 1 & 1 \\
\hline $\begin{array}{l}\text { Installation of an explosive device } \\
\text { in a crowded place, institution } \\
\text { (organization, company), } \\
\text { residential area, transportation }\end{array}$ & 19 & 36 & 0.941915 & 1 & 1 \\
\hline $\begin{array}{l}\text { Emergencies related to accidents } \\
\text { with people }\end{array}$ & 20 & 802 & 3.498542 & 1 & 2 \\
\hline
\end{tabular}


Table 4

Distribution of categories of importance depending on the probability values of an emergency

\begin{tabular}{cc}
\hline Range of change in the probability of an emergency, $\%$ & Category of importance \\
\hline up to 2 & 1 \\
$2-3$ & 2 \\
$3-6$ & 3 \\
$6-15$ & 4 \\
more than 15 & 5
\end{tabular}

Taking into account the adopted generalizations, a new relationship between the relative probabilities of emergencies and economic losses due to emergencies during 2000-2010 was built (Fig. 3).

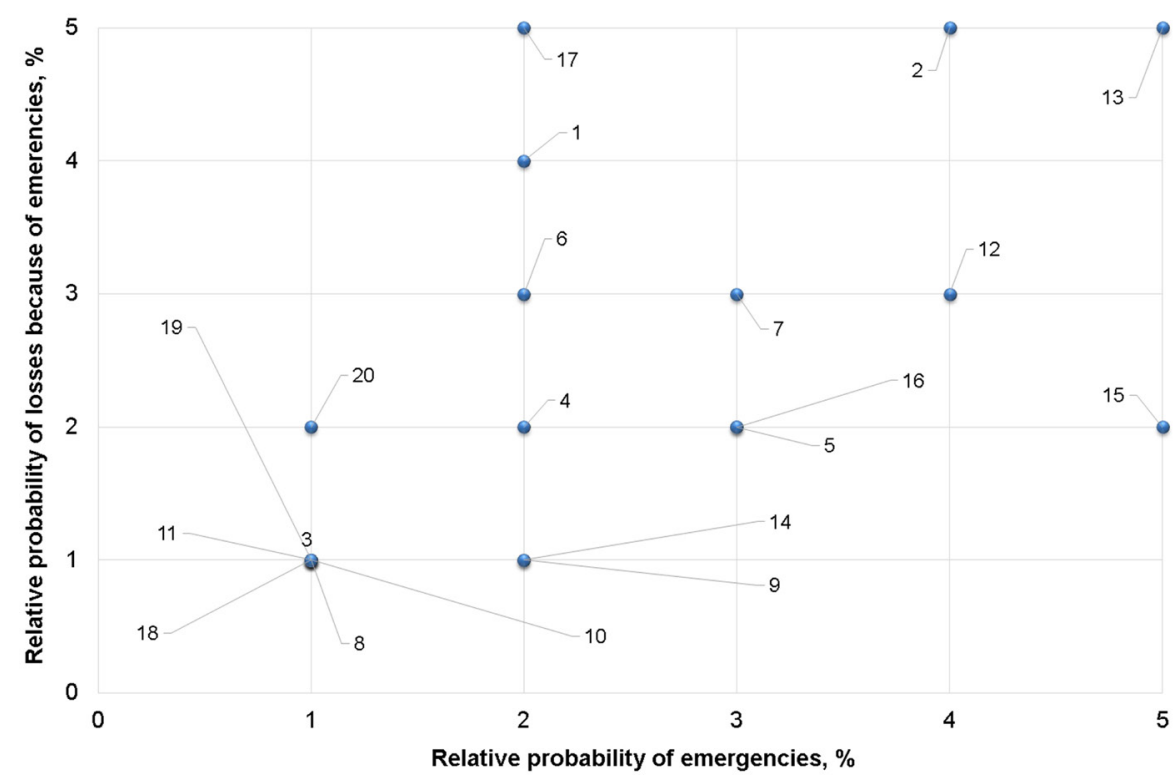

Fig. 3. The relationship between the relative probabilities of emergencies and economic losses due to emergencies during 2000-2010: 1 - Emergencies due to accidents or disasters at transportation; 2 - Emergencies due to fires, explosions; 3 - Emergencies as a result of accidents involving the emissions (threat of emissions) of hazardous chemicals, minerals at other sites (except traffic accidents); 4 - Emergencies due to the presence of harmful (polluting) and radioactive substances above MPC in the environment; 5 - Emergencies as a result of sudden destruction of buildings and structures; 6 - Emergencies due to accidents in electric power systems; 7 -Emergencies due to accidents in life support systems; 8 - Emergencies due to crash of telecommunication systems; 9 - Emergencies caused by accidents at treatment plants;

10 - Emergencies due to accidents in the systems of oil and gas industrial complex; 11 - Geophysical emergencies; 12 - Geological emergencies; 13 - Meteorological emergencies; 14 - Hydrological marine emergencies; 15 - Hydrological emergencies of surface waters; 16 - Emergencies related to fires in natural ecological systems; 17 - Medical and biological emergencies; 18 - Infringement on life of a statesman or a public figure; 19 - Installation of an explosive device in a crowded place, institution (organization, company), residential area, transportation; 20 - Emergencies related to accidents with people

\section{Results}

Taking into account the obtained results of the probability assessment of emergencies occurrence and economic losses due to them, the risk matrix is built according to the model used in the EU (Fig. 4).

The analysis of the obtained results shows that the high risk of economic losses in Ukraine is for emergencies due to fires, explosions and meteorological emergencies, which pose a per- 
manent threat not only to objects of critical infrastructure, but also to the population and the environment of the state.

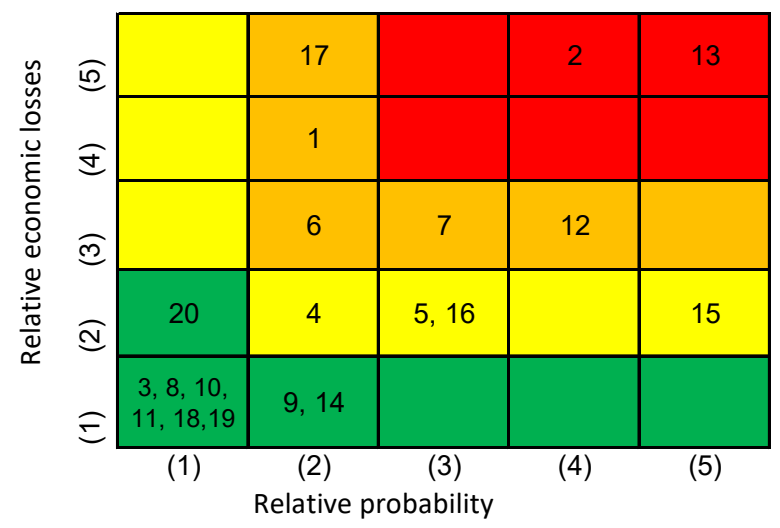

Fig. 4. Risk matrix of economic losses due to emergencies during 2000-2010:

1 - Emergencies due to accidents or disasters at transportation; 2 - Emergencies due to fires, explosions; 3 - Emergencies as a result of accidents involving the emissions (threat of emissions) of hazardous chemicals, minerals at other sites (except traffic accidents); 4 - Emergencies due to the presence of harmful (polluting) and radioactive substances above MPC in the environment;

5 - Emergencies as a result of sudden destruction of buildings and structures;

6 - Emergencies due to accidents in electric power systems; 7 - Emergencies due to accidents in life support systems; 8 - Emergencies due to crash of telecommunication systems;

9 - Emergencies caused by accidents at treatment plants; 10 - Emergencies due to accidents in the systems of oil and gas industrial complex; 11 - Geophysical emergencies; 12 - Geological emergencies; 13 - Meteorological emergencies;

14 - Hydrological marine emergencies; 15 - Hydrological emergencies of surface waters; 16 - Emergencies related to fires in natural ecological systems;

17 - Medical and biological emergencies; 18 - Infringement on life of a statesman or a public figure; 19 - Installation of an explosive device in a crowded place, institution (organization, company), residential area, transportation; 20 - Emergencies related to accidents with people.

$$
\text { Source: calculation of the authors }
$$

An increased risk level of economic losses is observed for biomedical emergencies, emergencies due to accidents, traffic accidents, emergencies due to accidents in electric power systems, emergencies due to accidents in life support systems, and geological emergencies. In modern conditions, threats of geological origin are becoming especially relevant for Ukraine, they have a steady tendency to intensify due to the effects of global climate change.

The average risk level of economic losses is observed for emergencies due to the presence of harmful (polluting) and radioactive substances above the MPC in the environment, emergencies due to sudden destruction of buildings and structures, hydrological emergencies, and emergencies related to fires in natural ecological systems.

From the management decision making point of view to the risk reduction of economic losses due to emergencies of various origins, it is clear that the primary attention should be focused on counteracting the negative consequences of meteorological threats, fires and explosions, including at the critical infrastructure objects.

In the general case, management and to some extent risk reduction involves the implementation of measures following certain scenarios:

- risk avoidance, i. e. the completion or denial of activities that causes risk;

- risks taking in order to take advantage of certain opportunities;

- exclusion the source of risk;

- change in probability;

- change of consequences;

- risk sharing with the other party through contracting or risk financing;

- maintaining the existing level of risk on the basis of an agreed solution. 
Given the complex interrelationships and interactions of the main factors of formation of threats of natural and man-made origin, an effective process of economic losses risk reduction will involve the combined implementation of several scenarios, which can be worked out using expert assessment methods. Particular attention in this case is drawn to the risk distribution with the other party through the contracting or risk financing, which is a relatively new and promising area for our country.

However, it should be taken into account that the risk matrix (Fig. 4) in determination of economic and environmental losses due to emergencies at the regional level (for example, in the Zaporizhzhia region of Ukraine) may slightly differ from the considered above, because the influence of natural hazards (meteorological emergencies and dangerous exogenous geological processes) in technogenically intensive regions of Ukraine can be changed to the increase of the impact of man-made factors associated with fires, explosions, industrial incidents at critical infrastructure objects.

\section{Discussion}

For most developed countries, especially EU and NATO member states, several fundamental approaches and principles are generally accepted, which are implemented in the creation of the critical infrastructure protection system with certain variations depending on specific conditions. Security and sustainability of critical infrastructure are among the priorities of the national security and defense sectors, and the relevant activities are regulated by several regulations, including at the national level. National critical infrastructure protection systems to ensure that their objectives are met must operate based on risk-based approaches, a clear division of powers and responsibilities for critical infrastructure usually determined by the responsible public authority or authorities.

Taking into consideration the growing risks of natural and man-made emergencies for critical infrastructure objects, it seems appropriate to recommend the National Security and Defense Council of Ukraine to consider the possibility to include the issues related to risk reduction of natural and man-made emergencies at objects of critical infrastructure at the territory of the Antiterrorist operation, in the negotiation process of the tripartite contact group in Minsk (Belarus).

The basis for the development of relevant regulations and programs in the field of critical infrastructure protection is the approval by the Cabinet of Ministers of Ukraine the Concept of creating a state system of critical infrastructure protection in Ukraine, the project of which was developed at the National Institute for Strategic Studies.

An important stage is the development and submission to the Verkhovna Rada of Ukraine the draft Law «On Critical Infrastructure Protection», which should address issues related to all aspects of creating a state system of critical infrastructure protection, including the body responsible for coordination of critical infrastructure protection activities.

Among them, the supreme importance belongs to the determination of the functions and authority of central executive bodies in the field of critical infrastructure protection, the rights, duties and responsibilities of owners and operators of critical infrastructure objects, the introduction of criteria for classifying of the objects as facilities of critical infrastructure on the base of criticality scale, the procedure for their certification and categorization.

At the same time priority should be given to the formation of criteria for classifying objects, including potentially dangerous ones, to critical infrastructure, assessing threats to critical infrastructure, developing plans to ensure the sustainability of critical infrastructure and forming a national system of cooperation in accordance with competence of relevant ministries.

Taking into consideration the significant growth of environmental and man-made threats in the ATO, it is advisable for the Cabinet of Ministers of Ukraine, the Ministry of Energy and Environmental Protection of Ukraine, the State Emergency Service of Ukraine to apply to international organizations UN, OSCE with a request to form an expert mission to conduct environmental risk assessment in the Donbass, to identify priority measures for the restoration of critical infrastructure objects and elimination of the consequences of emergency situations related to military activities.

In order to introduce a modern risk-oriented approach in the practice of specialized agencies in the field of critical infrastructure protection, a working group should be established at the State Emergency Service of Ukraine to develop proposals to determine the composition of participants and justify priorities for establishing a National Disaster Risk Reduction Platform in Ukraine. 
Prospects for further exploration in this area are related to the risks assessment of natural and man-made emergencies for critical infrastructure objects of Ukraine, their categorization by types and risk levels, as well as the development of reasonable measures to prevent emergencies with large-scale negative consequences for critical infrastructure objects.

The availability of actual and objective data on monitoring of current natural and man-made threats especially on economic losses from their implementation are important for risk assessment. These data have to be provided annually by the Ministry of Energy and Environmental Protection of Ukraine and the State Emergency Service of Ukraine in the form of reports on the state of the environment and the state of technogenic and natural safety, respectively.

In this regard, it is important to restore the full functioning of the Governmental Information and Analytical System for Emergency Situations and, on this basis, to improve the system for early detection of threats and reduce the risks of emergency situations of natural and man-made nature at critical infrastructure objects.

This system will provide effective interagency information interaction and support for management decision-making to prevent emergencies of various origins based on the use of modern methods of spatial analysis and mathematical modeling of emergency risks based on integrated processing of real-time, analytical, reference, expert and statistical data obtained from various information sources.

\section{Conclusions}

Currently in Ukraine there is a growing tendency to further decrease in the security level and reduction of the life-time duration of critical infrastructure objects, arising from over-exploitation of structures, constructions, equipment and engineering networks that operate on the brink of exhaustion of their resources and pose serious risks of natural and man-made emergencies for the safe operation of critical infrastructure objects.

In the context of the hybrid war in the east of Ukraine there is an increase in the risks of emergencies of man-made origin in the anti-terrorist operation area due to the destruction of many industrial and residential buildings as a result of military operations. The damages to critical infrastructure, including water treatment plants, chemical plants and agricultural enterprises caused by the military conflict in eastern Ukraine, poses a serious threat to the population and environment of the region.

A significant risk of emergencies of natural and man-made origin on the territory of the anti-terrorist operation is generated by the presence of a large number of flooded and semi-flooded mines in Luhansk and Donetsk regions (Ukraine), which have a permanent hydraulic connection with operating mines. The poor environmental situation in the coal-mining areas of Donbas is aggravated by the concentration of metallurgical and chemical companies, which increases the anthropogenic burden on the environment and poses real threats of man-made emergencies with large-scale negative consequences for the population.

The development and implementation of measures for risk reduction of emergencies of various origins at critical infrastructure objects is hampered by the lack of a national body responsible for coordination of the existing state defense and crisis response systems in the field of critical infrastructure protection. Today, the country does not have a single methodology for assessing threats and risks to critical infrastructure, which also complicates the development of measures to prevent and minimize the negative consequences of emergencies possible in Ukraine at critical infrastructure objects.

The current system for monitoring threats and reducing the risks of emergencies of various origins in the country does not provide a systematic and substantiated study of trends and the nature of changes in the main sources of threats to the environmental safety of the state and requires fundamental improvement. The state system of the population protection from natural and manmade disasters requires the introduction of a risk-based approach to effectively prevent disasters of various natures.

The efficiency and effectiveness of the system of early threats detection and reduction of risks of natural and man-made emergencies at critical infrastructure objects is reduced due to the inability of the Governmental Information and Analytical System for Emergency Situations to function in full. 


\section{References}

[1] Biryukov, D. S., Kondratov, S. I. (2016). Green Paper on critical infrastructure protection in Ukraine. National Institute for Strategic Studies, 176.

[2] Code of Civil Protection of Ukraine (2020). Available at: http://zakon3.rada.gov.ua/laws/show/5403-17

[3] Terminology on Disaster Risk Reduction. (2009). United Nations International Strategy for Disaster Reduction. Available at: https://www.undrr.org/publication/2009-unisdr-terminology-disaster-risk-reduction

[4] ISO 31000:2009. Risk management. Principles and guidelines. (2009). International Organization for Standardization.

[5] Global Assessment Report on Disaster Risk Reduction. Revealing Risk, Redefining Development (2011). United Nations. Available at: www.preventionweb.net/gar

[6] World Bank. 2010. Natural hazards, unnatural disasters: The economics of effective prevention (2011). Washington: World Bank and United Nations, 587.

[7] Bychenok, M. M, Ivanuta, S. P, Yakovlev, Ye. O. (2007). On complex assessment of life-threatening risks in potentially hazardous regions. Ecology and Resources, 17, 33-42.

[8] Leschinsky, O. L., Shkolny, O. V. (2005). Economic risk and methods of its measurement. Moscow, 112.

[9] Bernstein, P. L. (1996). Against the Gods: the Remarkable Story of Risk. John Wiley \& Sons, 383.

[10] Morgan, M. G., Henrion, M. (1990). Uncertainty: A Guide to Dealing with Uncertainty in Quantitative Risk and Policy Analysis. Cambridge University Press, 344. doi: http://doi.org/10.1017/cbo9780511840609

[11] Ivanuta, S. P. (2017). Environmental and man-made threats in the zone of military conflict in Eastern Ukraine. Strategic Panorama, 1, 53-60.

[12] Kachinsky, A. B. (2004). Security, Threats and Risks: Scientific Concepts and Mathematical Methods. Kyiv, 472.

[13] Beck, U. (1998). World Risk Society. Cambridge, 425.

[14] Long, S. O., Ivanchenko, V. V. et. al. (2016). Assimilation potential of the geological environment of Ukraine and its estimation. National Academy of Sciences of Ukraine, Institute of Telecommunications and Global Information Space, 176.

[15] Ivanyuta, S. P., Kachinsky, A. B. (2012). Ecological and natural-technogenic safety of Ukraine: a regional dimension of threats and risks. National Institute for Strategic Studies, 308.

[16] Opara, N. M., Dudar, N. I. (2013). Chadny gas: influence on the human body, ways of personal protection and safe behavior. Aspects of safety of work, life and environment of the person, 42-45. Available at: http://dspace.pdaa.edu.ua:8080/handle/ $123456789 / 798$

[17] Panov, E. N., Shilovich, I. L., Ivanenko, E. I., Buryak, V. V. (2012). Thermal and chemical aspects of formation co in the process of baking of electrodes. Eastern-European Journal of Enterprise Technologies, 4 (6 (58)), 15-18. Available at: http://journals.uran.ua/eejet/article/view/5586/5026

[18] Panov, Y., Gomelia, N., Ivanenko, O., Vahin, A., Leleka, S. (2019). Estimation of the effect of temperature, the concentration of oxygen and catalysts on the oxidation of the thermoanthracite carbon material. Eastern-European Journal of Enterprise Technologies, 2 (6 (98)), 43-50. doi: http://doi.org/10.15587/1729-4061.2019.162474

[19] Ivanenko, O., Panov, Y., Gomelia, N., Vahin, A., Leleka, S. (2020). Assessment of the Effect of Oxygen and Carbon Dioxide Concentrations on Gas Evolution During Heat Treatment of Thermoanthracite Carbon Material. Journal of Ecological Engineering, 21 (2), 139-149. doi: http://doi.org/10.12911/22998993/116326

[20] Environmental passport of Zaporizhzhia region for 2018 (2019). Available at: https://menr.gov.ua/news/33529.html

[21] Information and analytical information on the emergence of the National Assembly in Ukraine during 2016 (2017). Available at: http://www.dsns.gov.ua/ua/Dovidka-za-kvartal/57279.html

[22] Information and analytical information on the emergence of the National Assembly in Ukraine during the first quarter of 2017 (2017). Available at: http://www.dsns.gov.ua/ua/Dovidka-za-kvartal/61431.html

[23] The OSCE called for the protection of important infrastructure in the Donbass (2017). Available at: http://www.theinsider.ua/ politics/593595f08e98b/

[24] International Decade for Natural Disasters Reduction. Yokohama Strategy and Plan of Action for a safer world (1994). Available at: http://www.ifrc.org/Docs/idrl/I248EN.pdf

[25] Sendai Framework for Disaster Risk Reduction 2015-2030 (2015). Available at: http://www.unisdr.org

[26] Risk assessment methodologies for critical infrastructure protection. Part II: A new approach (2015). Publications Office of the European Union, 40. Available at: https://publications.jrc.ec.europa.eu 